\section{Chromosome Numbers of Rubus Species at the National Clonal Germplasm Repository}

\author{
Maxine M. Thompson ${ }^{1}$ \\ U.S. Department of Agriculture, Agricultural Research Service, National \\ Clonal Germplasm Repository, 33447 Peoria Road, Corvallis, OR 97333
}

Additional index words. raspberry, blackberry, cytology, germplasm

\begin{abstract}
The U.S. Dept. of Agriculture, Agricultural Research Service, National Clonal Germplasm Repository (NCGR), Corvallis, Ore., maintains Rubus germplasm representing worldwide diversity of the genus. Chromosome numbers were counted for 201 plants representing 124 taxa (species and varieties). There are new reports for 42 taxa, confirmation for 72 previously reported, and 10 counts for plants unidentified to species. The basic chromosome number was seven, and ploidy levels ranged from $2 x$ to $12 x$.
\end{abstract}

Rubus is a large genus with a worldwide distribution; species are found on all arable continents, from the lowland tropics to subarctic regions. The exact number of species is unknown because a worldwide taxonomic treatment of the genus has not been performed since that of Focke $(1910,1911,1914)$. Since then, many new species have been described and several studies have been performed on local floras, clarifying species and synonymies (e.g., Davis et al., 1967, 1968a, 1968b, 1969a, 1969b, 1970; Edees and Newton, 1988; Grierson and Long, 1983; Kalkman, 1984 1987; MacBride, 1938; Weber, 1972, 1981, 1986, 1988; Yü, 1985; Zandee and Kalkman, 1981). Estimates of the number of species range from 600 to 800 . Disagreements by taxonomists about species, particularly in the subgenus Rubus in Europe and eastern North America, are common because of the prevalence of interspecific hybridizations, polyploidy, and various forms of apomixis, all of which blur species boundaries. Arriving at an exact number likely never will be possible; obviously, there is an enormous amount of genetic diversity throughout the genus.

Many species provide an important source of food from commercial production of raspberries and blackberries as well as from the abundant fruit picked from wild plants. Among the several hundred Rubus species, only a small fraction have been exploited in breeding programs.

The U.S. Dept. of Agriculture, Agricultural Research Service, National Clonal Germplasm Repository (NCGR), Corvallis, Ore., has been assembling a collection of Rubus species, cultivars, and selections that greatly

Received for publication 13 Mar. 1995. Accepted for publication 14 July 1995. This research was funded by CRIS 5358-21000-011-000 at the U.S Dept. of Agriculture, Agricultural Research Service, National Clonal Germplasm Repository, Corvallis, Ore. The cost of publishing this paper was defrayed in part by the payment of page charges. Under postal regulations, this paper therefore must be hereby marked advertisement solely to indicate this fact.

${ }^{1}$ Collaborator. expands the genetic diversity available for plant breeders and other scientists. As far as possible, seeds, propagules, or both are obtained directly from wild populations to ensure a more accurate species identity. However, some species have been obtained from botanical gardens, nurseries, and breeder collections. Plants from these secondary sources are more likely to be incorrectly identified. The current collection at the NCGR consists of only a fraction of the world's diversity.

There is an exceptionally wide range in chromosome numbers ( $2 x$ to $14 x$ ) reported for Rubus species (Jennings, 1988; Nybom, 1980). Chromosome numbers are one aspect of germplasm characterization and as such can be helpful in verifying the plant identity. The numbers for cultivars and selections at the NCGR are reported separately (Thompson, 1995). My objective was to determine the chromosome number of one or more representatives of each species or variety growing at the NCGR.

\section{Materials and Methods}

Meristematic tissues used to obtain chromosome counts included shoot tips, root tips, and pollen mother cells (PMCs). Shoot tips on vigorous canes proved to be the most satisfactory. These rapidly growing meristems provided abundant mitotic metaphase figures throughout the growing season. In contrast, even when shoots were growing rapidly, root tips from pot-bound plants showed few cell divisions. PMCs provide reliable counts if the appropriate meiotic stages of late diakinesis, metaphase I, or metaphase II can be found. However, due to the varying flower bud sizes in the diverse germplasm, it is difficult to determine the correct stage of meiosis based on bud size. Furthermore, flower buds are available much less frequently than shoot tips. Samples were collected primarily from plants growing in screenhouses and less frequently from plants in a greenhouse or the field.

Detached shoot tips and root tips were placed immediately in cold water ( 2 to $4 \mathrm{C}$ ) and held overnight. To increase the frequency of meristematic cells in the squash, meristems with only a few leaf primordia were dissected. Then, these were placed in Carnoy's solution (three parts 95\% ethanol : one part glacial acetic acid) for 4 to $24 \mathrm{~h}$. Finally, the killingfixing solution was replaced with two changes of $70 \%$ ethanol before staining or storing tissues in a refrigerator. Flower buds were broken open to facilitate penetration of fluids, placed directly in the killing-fixing solution, and left for 20 to $24 \mathrm{~h}$. This solution was replaced with two or three changes of $70 \%$ ethanol, and buds were stored in the refrigerator. All tissues were stained in alcoholic hydrochloric acid-carmine (Snow, 1963) at room temperature for 3 to 7 days and then rinsed in two or three changes of $70 \%$ ethanol. After the excess stain was rinsed out, tissues were squashed or stored again in $70 \%$ ethanol.

Before squashing, the shoot or root tips were hydrolyzed in $45 \%$ acetic acid at $60 \mathrm{C}$ for 15 to $30 \mathrm{~min}$ to improve cell separation. Then, tissues were pulverized with a scalpel in a drop of acetic acid on a slide, and the coverslip was mounted with a small drop of Hoyer's medium (Anderson, 1954). Thumb pressure was applied on the coverslip to further separate cells, to flatten the metaphase plates, and to spread chromosomes. In some species with very high chromosome numbers, additional pressure applied directly above metaphase plates spread the chromosomes so that as many as 84 chromosomes could be counted accurately. For each accession, at least four counts of unambiguous chromosome configurations were made.

All plants at the NCGR are identified by a Rubus accession number for each plant for which counts were made and are presented Table 1.

\section{Results and Discussion}

Chromosome numbers are reported for 201 plants representing 114 Rubus taxa (species and varieties) and 10 unidentified accessions (Table 1). Of the identified taxa, 42 are new counts while the other 72 are confirmations of previous reports. In Table 1 and the subsequent discussion, species are presented according to their respective subgenera. The geographic origin, where known, is given for plants that were obtained from wild-growing populations of either natural or introduced species. Accessions from secondary sources were obtained from botanical gardens, arboreta, breeding programs, or nurseries, where plants were cultivated before being sent to the NCGR. For these plants, the geographic origin is often uncertain and errors in identity have been discovered. Labeling errors become increasingly probable as plants are successively propagated. Even when seeds are collected from a correctly labeled plant in a collection, they may actually have arisen from interspecific hybridization due to cross-pollination from nearby plants of other species. In the reference column of Table 1 , only the first chromosome number report for a species is cited.

The following subgenera, with the number 
Breeding, Cultivars, Rootstocks, \& Germplasm Resources

Table 1. Chromosome numbers of Rubus species at the U.S. Dept. of Agriculture, Agricultural Research Service, National Clonal Germplasm Repository, Corvallis, Ore.

\begin{tabular}{|c|c|c|c|c|c|}
\hline Species & $\begin{array}{c}\text { NCGR } \\
\text { inventory no. }\end{array}$ & $\begin{array}{c}\text { Chromosome } \\
\text { no. }\end{array}$ & $\begin{array}{c}\text { Geographic } \\
\text { origin }\end{array}$ & $\begin{array}{c}\text { Secondary } \\
\text { source }^{2}\end{array}$ & References \\
\hline \multicolumn{6}{|c|}{ European and southwestern Asian blackberries } \\
\hline \multirow{5}{*}{$\begin{array}{l}\text { Subgenus Rubus } \\
\text { armeniacus Focke } \\
\text { axillaris } \text { Lej. } \\
\text { caesius } \mathrm{L} \text {. }\end{array}$} & & & & & \\
\hline & 1195.001 & 28 & Sweden & 2 & Gustafsson, 1939 \\
\hline & 28.001 & 28 & Stavropol, Russia & & Longley, 1924 \\
\hline & 757.001 & 28 & Uzbekistan & & Longley, 1924 \\
\hline & 757.002 & 28 & Uzbekistan & & Longley, 1924 \\
\hline \multirow{2}{*}{ caucasicus Focke } & 54.001 & $28^{y}$ & Afghanistan & 1 & \\
\hline & 822.001 & $28^{y}$ & Unknown & 3 & \\
\hline cissburiensis Barton \& Riddelsd. hybrid & 753.001 & $28^{\mathrm{y}}$ & New Zealand (introd.)w & & \\
\hline conothyrsoides H.E. Weber & 1159.001 & $28^{y}$ & Germany & & \\
\hline cyri Juz. & 823.001 & $28^{y}$ & Unknown & 3 & \\
\hline drejeri $\mathrm{G}$. Jensen ex Lange & 55.001 & 28 & Unknown & 1 & Gustafsson, 1939 \\
\hline erythrops Edees \& A. Newton & 756.001 & $28^{y}$ & New Zealand (introd.)w & 4 & \\
\hline \multirow[t]{2}{*}{ hirtus Waldst. \& Kit. } & 51.001 & 28 & Former Yugoslavia & 1 & Gustafsson, 1933 \\
\hline & 56.001 & 28 & Former Yugoslavia & 1 & Gustafsson, 1933 \\
\hline insularis F. Aresch. & 1188.001 & 28 & Sweden & 2 & Gustafssson, 1933 \\
\hline laciniatus Willd. & 1596.001 & 28 & Australia (introd.) ${ }^{\mathrm{w}}$ & & Crane and Darlington, 1927 \\
\hline laciniatus Willd. variant & 413.001 & 28 & Oregon (introd.)w & & Crane and Darlington, 1927 \\
\hline miszczenkoi Juz. & 825.001 & $28^{\mathrm{y}}$ & Unknown & 3 & \\
\hline plicatus Weihe \& Nees & 44.001 & 28 & Unknown & 1 & Gustafsson, 1933 \\
\hline pyramidalis Kalt. hybrid & 1193.001 & $28^{y}$ & Sweden & 2 & \\
\hline \multirow{6}{*}{ sanctus Schreb. } & 482.001 & $14 y$ & Syria & & \\
\hline & 483.001 & $14^{y}$ & Syria & & \\
\hline & 484.001 & $14^{y}$ & Syria & & \\
\hline & 813.001 & $14^{y}$ & Turkey & 1 & \\
\hline & 1053.001 & $14^{y}$ & Northern Pakistan & & \\
\hline & 1054.001 & $14^{y}$ & Northern Pakistan & & \\
\hline slesvicensis Lange & 1088.001 & $42^{y}$ & Unknown & 1 & \\
\hline \multicolumn{6}{|c|}{ North American blackberries } \\
\hline hispidus $\mathrm{L}$. & 794.001 & 14 & North Carolina & & Aalders and Hall, 1966 \\
\hline trivialis Michx. & 260.001 & 14 & Georgia & & Yarnell, 1936 \\
\hline & 418.001 & 14 & Texas & & Yarnell, 1936 \\
\hline & 419.001 & 14 & Texas & & Yarnell, 1936 \\
\hline & 421.001 & 14 & Texas & & Yarnell, 1936 \\
\hline & 434.001 & 14 & Texas & & Yarnell, 1936 \\
\hline & 635.001 & 14 & Louisiana & & Yarnell, 1936 \\
\hline & 832.001 & 14 & Texas & & Yarnell, 1936 \\
\hline ursinus Cham. \& Schltdl. & 30.001 & 84 & Unknown & 1 & Darrow and Longley, 1933 \\
\hline & 197.001 & 84 & Oregon & & Darrow and Longley, 1933 \\
\hline & 611.001 & 84 & Idaho & & Darrow and Longley, 1933 \\
\hline & 615.001 & 84 & Washington & & Darrow and Longley, 1933 \\
\hline & 804.001 & 84 & Northern California & & Darrow and Longley, 1933 \\
\hline & & and Central Ame & blackberries & & \\
\hline adenotrichos Schltdl. & 1250.001 & $14^{y}$ & Ecuador & & \\
\hline robustus $\mathrm{C}$. Presl & 1264.001 & $14^{y}$ & Ecuador & & \\
\hline & 1273.001 & $14^{y}$ & Ecuador & & \\
\hline urticifolius Poir. & 1288.001 & $14^{y}$ & Ecuador & & \\
\hline Subgenus Idaeobatus (Focke) Focke & & & & & \\
\hline cockburnianus Hemsl. & 1724.001 & 14 & Unknown & 5 & Vaarama, 1954 \\
\hline columellaris Tutcher & 1622.001 & 14 & Guizhou, China & & Thompson and Zhao, 1993 \\
\hline corchorifolius L. f. & 1625.001 & 14 & Guizhou, China & & Iwatsubo and Naruhashi, 1993 \\
\hline & 1628.001 & 14 & Guizhou, China & & Iwatsubo and Naruhashi, 1993 \\
\hline coreanus Miq. & 1438.001 & 14 & China & 6 & Longley and Darrow, 1924 \\
\hline crataegifolius Bunge & 268.001 & 14 & Unknown & 7 & Vaarama, 1954 \\
\hline ellipticus $\mathrm{Sm}$. & 1052.001 & 14 & Northern Pakistan & & Malik, 1965 \\
\hline eustephanos Focke ex Diels & 1637.001 & $14^{y}$ & Guizhou, China & & \\
\hline & 1637.002 & $14^{y}$ & Guizhou, China & & \\
\hline
\end{tabular}




\begin{tabular}{|c|c|c|c|c|c|}
\hline Species & $\begin{array}{c}\text { NCGR } \\
\text { inventory no. }\end{array}$ & $\begin{array}{c}\text { Chromosome } \\
\text { no. }\end{array}$ & $\begin{array}{l}\text { Geographic } \\
\text { origin }\end{array}$ & $\begin{array}{c}\text { Secondary } \\
\text { source }^{z}\end{array}$ & References \\
\hline hawaiensis A. Gray & 399.001 & 14 & Hawaii & & Keep, 1958 \\
\hline \multirow[t]{2}{*}{ hirsutus Thunb. } & 8.001 & 14 & Japan & 1 & Jinno, 1951a \\
\hline & 266.004 & 14 & Unknown & 7 & Jinno, 1951a \\
\hline hoffmeisterianus Kunth \& Bouche & 1061.001 & $14^{y}$ & Northern Pakistan & & \\
\hline ideaus $\mathrm{L}$. & 1235.001 & 14 & Southern Kazakhstan & & Longley and Darrow, 1924 \\
\hline ikenoensis Lev. \& Vaniot & 1421.001 & 14 & Japan & & Iwatsubo and Naruhashi, 1992 \\
\hline illecebrosus Focke & 838.001 & 14 & Unknown & 8 & Longley, 1924 \\
\hline \multirow[t]{4}{*}{ innominatus $\mathrm{S}$. Moore } & 1039.001 & 14 & Jiangxi, China & & Longley and Darrow, 1924 \\
\hline & 1039.002 & 14 & Jiangxi, China & & Longley and Darrow, 1924 \\
\hline & 1039.003 & 14 & Jiangxi, China & & Longley and Darrow, 1924 \\
\hline & 1039.004 & 14 & Jiangxi, China & & Longley and Darrow, 1924 \\
\hline lasiostylus Focke & 425.001 & 14 & China & 8 & Longley and Darrow, 1924 \\
\hline lasiostylus Focke var. hubeiensis T.T.Yu et al. & 426.001 & $14^{y}$ & Hubei, China & 8 & \\
\hline \multirow[t]{2}{*}{ leucodermis Douglas ex Torrey \& A. Gray } & 14.001 & 14 & Unknown & 1 & Darrow and Longley, 1933 \\
\hline & 414.001 & 14 & Oregon & & Darrow and Longley, 1933 \\
\hline \multicolumn{6}{|l|}{$\begin{array}{l}\text { mcvaughianus Rzed. \& Calderon } \\
\text { microphyllus L.f. var. subcrataegifolius }\end{array}$} \\
\hline \multirow[t]{2}{*}{ Lev. \& Vaniot } & 158.001 & $14^{y}$ & Japan & & \\
\hline & 1608.001 & $14^{y}$ & Unknown & 11 & \\
\hline \multirow[t]{2}{*}{ minusculus Lev. \& Vaniot } & 161.001 & 14 & Japan & & Iwatsubo and Naruhashi, 1993 \\
\hline & 161.003 & 14 & Japan & & Iwatsubo and Naruhashi, 1993 \\
\hline \multirow[t]{3}{*}{ muelleri F.M. Bailey } & 762.001 & $28^{y}$ & Australia & 9 & \\
\hline & 763.001 & $28^{y}$ & Australia & 9 & \\
\hline & 763.002 & $28^{y}$ & Australia & 9 & \\
\hline \multirow[t]{3}{*}{ niveus Thunb. } & 269.001 & 14 & India & 12 & Thomas, 1940 \\
\hline & 1295.001 & 14 & Ecuador (introd.) ${ }^{\mathrm{w}}$ & & Thomas, 1940 \\
\hline & 1599.001 & 14 & New Guinea & 8 & Thomas, 1940 \\
\hline \multirow[t]{2}{*}{ occidentalis $\mathrm{L}$. } & 541.001 & 14 & Arkansas & & Longley, 1924 \\
\hline & 641.001 & 14 & Illinois & & Longley, 1924 \\
\hline palmatus Thunb. ex Murray & 2.001 & 14 & Japan & & Jinno, $1951 \mathrm{~b}$ \\
\hline palmatus Thunb. ex Murray & & & & & \\
\hline var. coptophyllus (A. Gray) Kuntze & 1610.001 & $14^{y}$ & Unknown & 11 & \\
\hline parvifolius $\mathrm{L}$. & 5.001 & 14 & Japan & 1 & Jinno, 1951a \\
\hline & 180.001 & 14 & Taiwan & & Jinno, 1951a \\
\hline & 1615.001 & 14 & Unknown & 11 & Jinno, 1951a \\
\hline parvifolius $\mathrm{L}$. ( $4 x$ clone) & 53.001 & 28 & Unknown & 1 & \\
\hline phoenicolasius Maxim. & 163.001 & 14 & Japan & & Longley and Darrow, 1924 \\
\hline & 1612.001 & 14 & Unknown & 11 & Longley and Darrow, 1924 \\
\hline pinfaensis Lev. \& Vaniot & 1665.001 & $14^{y}$ & Guizhou, China & & \\
\hline & 1665.002 & $14^{y}$ & Guizhou, China & & \\
\hline pungens Cambess. & 46.002 & 14 & Unknown & 1 & Iwatsubo and Naruhashi, 1992 \\
\hline rosifolius $\mathrm{Sm}$. & 188.001 & 14 & Java, Indonesia & & Thompson and Zhao, 1993 \\
\hline rosifolius $\mathrm{Sm}$. var. coronarius (Sims.) Focke & 1604.001 & $14^{y}$ & Unknown & 11 & \\
\hline sachalinensis Lev. & 167.001 & 28 & Honshu Island, Japan & & Rozanova, 1939 \\
\hline & 626.001 & 28 & Jilin, China & & Rozanova, 1939 \\
\hline simplex Focke & 428.001 & 14 & China & 8 & Vaarama, 1954 \\
\hline spectabilis Pursh & 4.001 & 14 & California & 1 & Darrow and Longley, 1933 \\
\hline strigosus Michx. & 17.001 & 14 & Unknown & 1 & Longley and Darrow, 1924 \\
\hline & 18.001 & 14 & Unknown & 1 & Longley and Darrow, 1924 \\
\hline & 20.001 & 14 & Unknown & 1 & Longley and Darrow, 1924 \\
\hline & 157.001 & 14 & Wyoming & & Longley and Darrow, 1924 \\
\hline & 182.001 & 14 & Alaska & & Longley and Darrow, 1924 \\
\hline & 183.001 & 14 & Alaska & & Longley and Darrow, 1924 \\
\hline & 211.001 & 14 & Idaho & & Longley and Darrow, 1924 \\
\hline & 212.001 & 14 & Idaho & & Longley and Darrow, 1924 \\
\hline & 214.001 & 14 & Oregon & & Longley and Darrow, 1924 \\
\hline & 257.001 & 14 & Idaho & & Longley and Darrow, 1924 \\
\hline & 591.001 & 14 & Unknown & 13 & Longley and Darrow, 1924 \\
\hline & 592.001 & 14 & Unknown & 13 & Longley and Darrow, 1924 \\
\hline & 607.001 & 14 & Idaho & & Longley and Darrow, 1924 \\
\hline & 610.001 & 14 & Idaho & & Longley and Darrow, 1924 \\
\hline & 613.001 & 14 & Alberta, Canada & & Longley and Darrow, 1924 \\
\hline & 1103.001 & 14 & Alaska & & Longley and Darrow, 1924 \\
\hline & 1137.001 & 14 & Wyoming & & Longley and Darrow, 1924 \\
\hline sumatramus Miq. & 7.001 & 14 & Japan & 1 & Iwatsubo and Naruhashi, 1992 \\
\hline thibetanus Franch. hybrid & 264.001 & $14^{y}$ & Unknown & 7 & \\
\hline trianthus Focke & 1044.001 & 14 & Jiangxi, China & & Thompson and Zhao, 1993 \\
\hline trifidus Thunb. ex Murray & 3.001 & 14 & Japan & 1 & Jinno, $1951 b$ \\
\hline & 1429.001 & 14 & Japan & & Jinno, $1951 b$ \\
\hline Subgenus Anaplobatus (Focke) Focke & & & & & \\
\hline deliciosus Torr. & 1021.001 & $14^{\mathrm{y}}$ & Oklahoma & & \\
\hline neomexicanus A. Gray & 58.001 & $14^{y}$ & Unknown & 1 & \\
\hline & 436.001 & $14^{y}$ & Arizona & 14 & \\
\hline odoratus $\mathrm{L}$. & 11.001 & 14 & Unknown & 1 & Longley, 1924 \\
\hline parviflorus Nutt. & 13.001 & 14 & Unknown & 1 & Darrow and Longley, 1933 \\
\hline
\end{tabular}




\begin{tabular}{|c|c|c|c|c|c|}
\hline$\underline{\text { Species }}$ & $\begin{array}{c}\text { NCGR } \\
\text { inventory no. }\end{array}$ & $\begin{array}{c}\text { Chromosome } \\
\text { no. }\end{array}$ & $\begin{array}{c}\text { Geographic } \\
\text { origin }\end{array}$ & $\begin{array}{c}\text { Secondary } \\
\text { source }^{z}\end{array}$ & References \\
\hline \multicolumn{6}{|l|}{ Subgenus Malachobatus (Focke) Focke } \\
\hline assamensis Focke & 1701.002 & 28 & Guizhou, China & & Thompson and Zhao, 1993 \\
\hline bambusarum Focke & 1602.001 & 28 & Unknown & 11 & Keep, 1958 \\
\hline buergeri Miq. & 1603.001 & 56 & Unknown & 11 & Jinno, 1951a \\
\hline formosensis Kuntze & 174.001 & 28 & Taiwan & & Thompson and Zhao, 1993 \\
\hline hayata-koidzumi Naruh. & 178.001 & 28 & Taiwan & & Thompson and Zhao, 1993 \\
\hline henryi Hemsl. \& Kuntze & 152.001 & 28 & China & & Keep, 1958 \\
\hline \multirow{3}{*}{ hillii F. Muell. } & 1199.001 & $42^{y}$ & Australia & & \\
\hline & 1199.002 & $42^{y}$ & Australia & & \\
\hline & 1199.012 & $42^{y}$ & Australia & & \\
\hline \multirow[t]{2}{*}{ hunanensis Hand.-Mazz. } & 1715.001 & $28^{y}$ & Guizhou, China & & \\
\hline & 1715.002 & $28^{y}$ & Guizhou, China & & \\
\hline ichangensis Hemsl. \& Kuntze & 1606.001 & 28 & Unknown & 11 & Iwatsubo and Naruhashi, 1992 \\
\hline \multirow{3}{*}{ irenaeus Focke } & 1607.001 & 42 & Unknown & 11 & Thompson and Zhao, 1993 \\
\hline & 1697.001 & 42 & Guizhou, China & & Thompson and Zhao, 1993 \\
\hline & 1697.002 & 42 & Guizhou, China & & Thompson and Zhao, 1993 \\
\hline \multirow[t]{2}{*}{ lambertianus Ser. } & 181.001 & 28 & Japan & & Iwatsubo and Naruhashi, 1992 \\
\hline & 1210.001 & 28 & Japan & 15 & Iwatsubo and Naruhashi, 1992 \\
\hline lambertianus Ser. var. glaber Hemsl. & 429.001 & $28^{y}$ & Hubei, China & & \\
\hline \multirow[t]{2}{*}{ multibracteatus Lev. \& Vaniot } & 1642.001 & 28 & Guizhou, China & & Thompson and Zhao, 1993 \\
\hline & 1645.001 & 28 & Guizhou, China & & Thompson and Zhao, 1993 \\
\hline setchuenensis Bureau \& Franch. & 1613.001 & 28 & Unknown & 11 & Thompson and Zhao, 1993 \\
\hline \multirow{3}{*}{$\begin{array}{l}\text { setchuenenis Bureau \& Franch. } \\
\text { swinhoei Hance }\end{array}$} & 1695.001 & 28 & Guizhou, China & & Thompson and Zhao, 1993 \\
\hline & 1671.001 & $28^{y}$ & Guizhou, China & & \\
\hline & 1671.002 & $28^{y}$ & Guizhou, China & & \\
\hline \multirow[t]{2}{*}{ tephrodes Hance } & 1041.001 & 28 & Anhui, China & & Vaarama, 1954 \\
\hline & 1713.002 & 28 & Guizhou, China & & Vaarama, 1954 \\
\hline \multicolumn{6}{|l|}{ tephrodes Hance var. ampliflorus } \\
\hline (Lev. \& Vaniot) Hand.-Mazz. & 1043.001 & $28^{y}$ & Jiangxi, China & & \\
\hline \multicolumn{6}{|l|}{ Subgenus Cylactis (Raf.) Focke } \\
\hline $\begin{array}{l}\text { arcticus } \mathrm{L} \text {. } \\
\text { arcticus } \mathrm{L} \text {. subsp. X stellarcticus }\end{array}$ & \multicolumn{4}{|c|}{ arcticus $\mathrm{L}$. subsp. X stellarcticus } & Vaarama, 1939 \\
\hline G. Larsson & 32.001 & $14^{y}$ & Sweden & 1 & \\
\hline \multirow[t]{2}{*}{ lasiococcus A. Gray } & 261.001 & $14^{y}$ & Oregon & & \\
\hline & 1619.001 & $14^{y}$ & Oregon & & \\
\hline nepalensis (Hook. f.) Kuntze & 1609.001 & $28^{y}$ & Uncertain & 11 & \\
\hline pedatus $\mathrm{Sm}$ & 191.001 & 14 & Washington & & Taylor and Mulligan, 1968 \\
\hline pubescens Raf. & 1094.001 & 14 & Oregon & 1 & Vaarama, 1954 \\
\hline Subgenus Dalibardastrum (Focke) Yü \& & & & & & \\
\hline amphidasys Focke ex Diels & 1693.001 & 42 & Guizhou, China & & Thompson and Zhao, 1993 \\
\hline tricolor Focke & 1614.001 & 28 & Unknown & 11 & Keep, 1954 \\
\hline tsangorum Hand.-Mazz. & 1674.001 & $28^{y}$ & Fujian/Hunan, China & 6 & \\
\hline Subgenus Orobatus Focke & & & & & \\
\hline glabratus Kunth & 1251.001 & $42^{y}$ & Ecuador & & \\
\hline nubigenus Kunth & 1257.001 & $42^{y}$ & Ecuador & & \\
\hline & 1257.002 & $42^{y}$ & Ecuador & & \\
\hline roseus Poir. & 1266.002 & $42^{y}$ & Ecuador & & \\
\hline Subgenus Chamaebatus (Focke) Focke & & & & & \\
\hline nivalis Douglas ex Hook. & 1374.001 & $14^{y}$ & Oregon & & \\
\hline pectinellus Maxim. & 179.001 & 42 & Taiwan & & Jinno, 1951a \\
\hline & 1426.001 & 42 & Honshu Island, Japan & & Jinno, 1951a \\
\hline Subgenus Micranthobatus (Fritsch.) Kal & & & & & \\
\hline cissoides A. Cunn. & 722.001 & $28^{y}$ & New Zealand & & \\
\hline schmidelioides A. Cunn. & 741.001 & $28^{y}$ & New Zealand & & \\
\hline squarrosus Fritsch & 739.001 & $28^{y}$ & New Zealand & & \\
\hline Natural inter-subgeneric hybrid & & & & & \\
\hline glaucus Benth. & 759.001 & 28 & Ecuador & 4 & Williams et al., 1949 \\
\hline Undetermined species & & & & & \\
\hline sp. & 219.001 & 28 & Scotland & & \\
\hline & 248.001 & 28 & England & & \\
\hline & 328.001 & 28 & Ireland & & \\
\hline & 542.002 & 14 & Missouri & & \\
\hline & 580.001 & 28 & Missouri & & \\
\hline & 582.001 & 28 & Missouri & & \\
\hline & 1150.001 & 14 & Pennsylvania & & \\
\hline & 1151.001 & 35 & Pennsylvania & & \\
\hline & 1152.001 & 35 & Pennsylvania & & \\
\hline & 1675.001 & 14 & Guizhou, China & & \\
\hline
\end{tabular}

${ }^{2}$ Plant material received from an intermediary source where plants were grown, rather than directly from the original geographic region where collected. $1=$ Western Washington Research and Extension Center, Puyallup, Wash.; 2 = Frediriksdal Botanical Gardens, Helsingborg, Sweden; 3 = Vavilov Institute, St. Petersberg, Russia; 4 = Riwaka Research Station, Crop Research Division, Motueka, New Zealand; 5 = Arnold Arboretum, Jamaica Plains, Mass.; 6 = Nanjing Botanical Garden, Nanjing, China; 7 = East Malling Research Station, Maidstone, Kent, England; 8 = Dept. of Botany and Plant Pathology, Oregon State Univ., Corvallis; 9 = Australian National Botanical Gardens, Sydney; $10=$ Agriculture Canada Research Station, Vancouver, B.C.; $11=$ Heronswood Nursery, Kingston, Wash.;

12 = U.S. Dept. of Agriculture Plant Introduction Station, Miami; 13 = Washington State Univ., Pullman, Wash.; $14=$ Washington Park Arboretum, Seattle; and 15 = Toyama Univ., Toyama, Japan.

${ }^{y} \mathrm{New}$ chromosome number report.

${ }^{\mathrm{w}}$ Introduced to that country; originated elsewhere. 
of species or varieties of each, were available for study: Rubus (34), Idaeobatus (41), Anaplobatus (4), Malachobatus(17), Cylactis (6), Dalibardastrum (3), Orobatus (3), Chamaebatus (2), and Micranthobatus (3). Plants were not available yet from the subgenera Chamaemorus, Lampobatus, and Comaropsis, each of which consists of very few species. Counts are given for 10 taxa as yet unidentified.

Subgenus Rubus (blackberries). In this study, the subgenus Rubus is discussed according to the geographic origin of the species. In the European-West Asian group, chromosomes were counted for 40 accessions representing 27 taxa. Chromosome numbers for species in the section Rubus include the previously reported diploids $R$. canescens and $R$. ulmifolius. The new report of $2 x$ for $R$. sanctus might be expected because of its close relationship to R. ulmifolius. The other 19 species in the section Rubus are tetraploid. Species for which $4 x$ is reported for the first time include $R$. caucasicus, $R$. cissburiensis hybrid, $R$. conothyrsoides, $R$. cyri, $R$. erythrops, $R$. georgicus, $R$. grabowski, and $R$. miszczkenkoi. The count of $4 x$ for $R$. grabowski is inconsistent with the $3 x$ counts that have been reported for its proposed synonyms $R$. thrysanthus Focke and $R$. thrysoideus Wimm. Either $R$. grabowski is not synonymous with these species or the NCGR has a misidentified accession. Only two species were available in the section Corylifolii: $R$. slesvicensis $(6 x)$ is a new report, and $R$. wahlbergii $(5 x)$ was confirmed. The only species in the section Caesii, R. caesius, (4x) was confirmed.

The chromosome numbers that I report for the limited sampling of the abundant European species are consistent with Gustafsson's (1943) conclusion regarding the ploidy levels in the major Rubus sections. That is, the section Rubus (Moriferi veri) has predominantly tetraploids, with only two basic diploid species and a few triploids that are mainly associated with two form complexes, $R$. nitidus Weihe $\&$ Nees and $R$. thyrsoideus Wimm. (now collectively called $R$. grabowski Weihe ex Gunther et al.). Section Corylifolii consists of tetraploids but also a few pentaploid and hexaploid species.

At the NCGR collection, North American blackberries are represented by plants of only four species. The three species from eastern North America, $R$. trivialis, $R$. hispidus, and $R$. canadensis, have previously been reported to be diploids, counts which I confirmed. However, in $R$. canadensis, $3 x$ forms also are found commonly, one of which is among the NCGR accessions. Aalders and Hall (1966) found $R$. hispidus to be $2 x$, as reported in my study, whereas Longley (1924) reported $5 x$ for this species; he may have had a misidentified plant, perhaps an interspecific hybrid.

The one species native to the Pacific states, $R$. ursinus, consists of a polyploid complex with $2 n$ numbers of $42,56,63,70,77$, and 84 (Brown, 1943). This species' range is throughout the western regions of California, Oregon, Washington, and Idaho, and British Columbia, Canada. In most of California, the pre- dominant $2 n$ number is 56 , whereas 84 predominates from northern California through Oregon, Washington, and Idaho. The other chromosome numbers occur less frequently and mostly in the central California coastal region or in northern California, where 56and 84-chromosome forms overlap. The NCGR accessions, all of which are $12 x$, were collected from regions where this high number is expected: in northern California and Oregon, Idaho, and Washington.

South and Central American blackberry species are poorly represented at the NCGR, with only three species, all from Ecuador. To my knowledge, this paper is the first to report the chromosome numbers for $R$. adenotrichos $(2 x), R$. robustus $(2 x)$, and $R$. urticifolius $(2 x)$. These counts are consistent with that of $R$. bogotensis ( $2 x$ ), the only other South American blackberry species that has a reported chromosome number (Dale and Ingram, 1981; Gustafsson, 1939). These four species are all included in Focke's $(1910,1911,1914)$ section Floribundi. More plant collections are needed from South and Central America so that the extent of the primary diploid basic number in Rubus from this region can be determined.

Subgenus Idaeobatus (raspberries). Of the 41 accessions in this subgenus whose chromosomes were counted, all but three were diploids. New counts are reported for 10 taxa: $R$. eustephanos $(2 x), R$. hoffmeisterianus $(2 x), R$. lasiostylus var. hubeiensis $(2 x), R$. mcvaughianus $(2 x)$, $R$. microphyllus var. subcrataegifolius $(2 x), R$. muelleri $(4 x), R$. palmatus var. coptophyllus $(2 x), R$. pinfaensis $(2 x), R$. rosifolius var. coronarius $(2 x)$, and a presumed hybrid of $R$. thibetanus $(2 x)$.

Polyploidy is not common in this subgenus. Of the 40 species counted, only two are tetraploid. Stanley and Ross (1983) reported that $R$. muelleri (4x) from Australia is a synonym of $R$. fraxinifolius Poir. However, A.R. Bean (personal communication) considers $R$. muelleri to be a separate species. The other $4 x$ species, $R$. sachalinensis, which is widespread in Northeast Asia, was reported to have arisen through autotetraploidy from the wild $R$. idaeus (Rozanova, 1939). Two accessions of $R$. sachalinensis from East Asia (one from northern Japan and one from China) confirm the $4 x$ count. The $2 x$ count for the wild raspberry accession collected near Almaty, Kazakstan, indicates that this plant is R. idaeus. Unless the two species overlap, $R$. sachalinensis may not extend to this region. Based on morphological traits, Rozanova (1939) reported that $R$. strigosus in western North America was more similar to $R$. sachalinensis in northeastern Asia than it was to $R$. strigosus in eastern North America. Hitchcock et al. (1961) perpetuated the concept that sachalinensis (albeit as a subspecies of $R$. idaeus) is one of the wild raspberry forms in northwestern North America. To help clarify this taxonomy, the chromosome number for 17 accessions of wild raspberry from the northwestern states, including Alaska, was determined; in all cases, these accessions were diploid. Therefore, based on cytological criteria only, all North Ameri- can raspberries are designated $R$. strigosus, rather than the northwestern populations being included in $R$. sachalinensis. The third $4 x$ Idaeobatus accession was an induced tetraploid $R$. parvifolius clone whose ploidy level was confirmed.

Subgenus Anaplobatus. This subgenus is represented by four species, all of which are diploid. To my knowledge, I am the first to report that $R$. neomexicanus is $2 x$; I also confirm $R$. odoratus $(2 x)$ and $R$. parviflorus $(2 x)$. I found $R$. deliciosus to be $2 x$, whereas Longley (1924) reported it as $3 x$. Counts of more individuals in this species are necessary to determine if, indeed, $2 x$ and $3 x$ forms exist in wild populations. I suspect, however, that Longley (1924) may have had an aberrant individual $3 x$ plant arising from an unreduced gamete or from interspecific hybridization.

Subgenus Malachobatus. Chromosome studies in the subgenus Malachobatus have been performed only recently (Naruhashi and Iwatsubo, 1993; Nybom, 1986; Thompson and Zhao, 1993), so that, currently, chromosome numbers are available for $\approx 37$ species, all of which are polyploid $(4 x, 6 x, 8 x$, and $14 x)$, with $4 x$ being the predominant ploidy level. In my study, I report chromosome numbers of 17 taxa-only three of these are new counts: $R$. hunanensis ( $4 x)$, R. swinhoei ( $4 x$ ), and $R$. hillii $(6 x)$. Although Stanley and Ross (1983) consider $R$. hilliit to be a synonym of $R$. moluccanus L., A.R. Bean (personal communication) and Kalkman (1984) prefer to keep $R$. hillii separate from the typical $R$. moluccanus var. moluccanus, which also is present in northern Australia. Nybom (1986) reported $R$. moluccanus from Indonesia, a close relative of $R$. hillii, to be $4 x$. I made the counts of $6 x$ for $R$. hillii on three plants grown from one seed lot received from northern Australia. These different counts for $R$. hillii and $R$. moluccanus support the concept of their being two separate species. Rubus moluccanus is an extremely variable species that may represent a species complex, including $R$. hillii, with varying chromosome numbers. I found two new counts for varieties of species whose numbers were previously reported [i.e., $R$. lambertianus var. glaber (4x) and $R$. tephrodes var. ampliflorus $(4 x)]$.

Subgenus Cylactis. Of the six taxa available in this subgenus, five are diploid and one (R. nepalensis) is tetraploid. Ireport new counts for $R$. arcticus subsp. X stellarcticus $(2 x), R$. lasiococcus $(2 x)$, and $R$. nepalensis $(4 x)$ and confirm counts for previously established $R$. $\operatorname{arcticus}(2 x), R$. pedatus $(2 x)$, and $R$. pubescens $(2 x)$.

Subgenus Dalibardastrum. The three species for which counts were made are all polyploid. This paper is a new report for $R$. tsangorum $(4 x)$ and a confirmation of previous reports for $R$. amphidasys $(6 x)$ and $R$. tricolor $(4 x)$.

Subgenus Orobatus. All three species counted in this subgenus, $R$. glabratus $(6 x), R$. nubigenus $(6 x)$, and $R$. roseus $(6 x)$, are hexaploid and represent new reports. This number is consistent with the only other published report for a species in this subgenus, $R$. 
macrocarpus Benth. (6x) (Dale and Ingram, 1981).

Subgenus Chamaebatus. The two species available have different ploidy levels. To my knowledge, $R$. nivalis $(2 x)$ is newly reported in my study, whereas $R$. pectinellus $(6 x)$ was previously reported.

Subgenus Micranthobatus. This subgenus was originally published by Fritsch (1886) as a section that included a few Rubus species in New Zealand and Australia. Focke (1910, $1911,1914)$ then placed these species in Lampobatus, a subgenus that included a small group of diverse, geographically scattered species. Kalkman (1987) considers that the New Zealand and Australian Rubus species, along with a few others, are distinct enough to warrant their separate subgenus (i.e., Micranthobatus). To my knowledge, this is the first report on the chromosome numbers of three species in this subgenus: $R$. cissoides $(4 x), R$. schmidelioides (4x), and $R$. squarrosus $(4 x)$. The number is consistent with the only other report for this subgenus, $R$. parvus Buchanan $(4 x)$, by Beuzenberg and Hair (1983).

Natural intersubgeneric hybrid. The count presented here for $R$. glaucus (4x) confirms previous reports. Darrow (1952) first proposed that this species arose from an interspecific hybrid between the black raspberry and a diploid tropical blackberry, followed by chromosome doubling that created a fertile allopolyploid. Jennings (1978) provided further evidence for this hypothesis based on the nature of anthocyanin pigments in the fruit of $R$. glaucus and its putative parents. The relatively true breeding behavior when selfed further supports this concept (Darrow, 1952).

Undetermined species. Counts are given for 10 accessions that have not been identified to species yet. All but one were blackberries (subgenus Rubus) collected from wild populations in North America or in Great Britain. The other one, in the subgenus Ideaobatus, was collected in Guizhou Province, China. Chromosome numbers will assist in the eventual identification of these plants.

This list of chromosome numbers for 124 Rubus taxa represents only $\approx 55 \%$ of the species currently held at the NCGR. Counts could not be made on the 97 other accessions that are stored as seeds only. Knowledge of the chromosome number is important for use of germplasm by breeders who want to make effective interspecific hybridizations and for taxonomic and evolutionary studies.

Plant materials are available to researchers on request, depending on the accession, either as seeds, cuttings, or in vitro cultures. An inventory list of available plants can be obtained from Kim Hummer, curator, National Clonal Germplasm Repository, 33447 Peoria Rd., Corvallis, OR 97333.

\section{Literature Cited}

Aalders, L.E. and I.V. Hall. 1966. A cytotaxonomic survey of the native blackberries of Nova Scotia. Can. J. Genet. Cytol. 8:528-532.

Anderson, L.E. 1954. Hoyer's solution as a rapid permanent mounting medium for bryophytes. Bryologist 57:242-244.
Brown, S.W. 1943. The origin and nature of variability in the Pacific coast blackberries (Rubus ursinus Cham. \& Schlecht. and R. lemurum sp. nov.) Amer. J. Bot. 30:686-697.

Crane, M.B. and C.D. Darlington. 1927. The origin of new forms in Rubus. 1. Genetica 9:241-276.

Dale, A. and R. Ingram. 1981. Chromosome numbers of some South American blackberries. Hort. Res. 21:107.

Darrow, G.M. 1952. Rubus glaucus, the Andean blackberry of Central America and northern South America. Ceiba 3:97-101.

Darrow, G.M. and A.E. Longley. 1933. Cytology and breeding of Rubus macropetalus, the logan, and related blackberries. J. Agr. Res. 47:315-330.

Davis, H.A., A.M. Fuller, and T. Davis. 1967. Contributions toward the revision of the Eubati of eastern North America. Castanea 32:20-37.

Davis, H.A., A.M. Fuller, and T. Davis. 1968a. Contributions toward the revision of the Eubati of eastern North America. Castanea 33:50-76.

Davis, H.A., A.M. Fuller, and T. Davis. 1968b. Contributions toward the revision of the Eubati of eastern North America. Castanea 33:206-240.

Davis, H.A., A.M. Fuller, and T. Davis. 1969a. Contributions toward the revision of the Eubati of eastern North America. Castanea 34:157-179.

Davis, H.A., A.M. Fuller, and T. Davis. 1969b. Contributions toward the revision of the Eubati of eastern North America. Castanea 34:235-266.

Davis, H.A., A.M. Fuller, and T. Davis. 1970. Contributions toward the revision of the Eubati of eastern North America. Castanea 35:176-194.

Edees, E.S. and A. Newton. 1988. Brambles of the British Isles. The Ray Society, London.

Focke, W.O. 1910. Species Ruborum Monographiae generis Rubi Podromus. Biblioth. Bot. 17 (72 Part 1): $1-120$.

Focke, W.O. 1911. Species Ruborum Monographiae generis Rubi Podromus. Biblioth. Bot. 17 (72 Part 2):121-223.

Focke, W.O. 1914. Species Ruborum Monographiae generis Rubi Podromus. Biblioth. Bot. 17(83):1274.

Fritsch, K. 1886. Die Rubi Neuseelands. Öster. Bot. Zeit. 36:257-261.

Grierson, A.J.C. and D.G. Long. 1983. Flora of Bhutan. vol. 1, Part 1. Royal Botanic Garden, Edinburgh.

Gustafsson, Å. 1933. Chromosomenzahlen in der gattung Rubus. Hereditas 18:77-80.

Gustafsson, Å. 1939. Differential polyploidy within the blackberries. Hereditas 25:33-47.

Gustafsson, A. 1943. The genesis of the European blackberry flora. Acta Univ. Lund 39:1-200.

Heslop-Harrison, Y. 1953. Cytological studies in the genus Rubus L. 1. Chromosome numbers in the British Rubus flora. New Phytol. 52:22-39.

Hitchcock, C.L., A. Cronquist, M. Ownbey, and J.W. Thompson. 1961. Vascular plants of the Pacific Northwest. vol. 3. Univ. of Washington Press, Seattle.

Iwatsubo, Y. and N. Naruhashi. 1992. Cytotaxonomical studies of Rubus (Rosaceae) I. Chromosome numbers of 20 species and 2 natural hybrids. J. Jpn. Bot. 67:270-275.

Iwatsubo, Y. and N. Naruhashi. 1993. Cytotaxonomical studies of Rubus (Rosaceae) II. Chromosome numbers of 21 species and 6 natural hybrids. J. Jpn. Bot. 68:159-165.

Jennings, D.L. 1978. The blackberries of South America-An unexplored reservoir of germplasm. Fruit Var. J. 32:61-63.

Jennings, D.L. 1988. Raspberries and blackberries: Their breeding, diseases and growth. Academic, London.

Jinno, T. 1951a. Chromosome numbers in Rubus I. La Kromosomo 9-10:360-361.

Jinno, T. 1951b. The chromosomes in Rubus II. Jpn. J. Genet. 26:133-135.

Jinno, T. 1958. Cytogenetic and cytoecological studies on some Japanese species of Rubus I. Chromosomes. Bot. Mag. Tokyo 71:15-23.

Kalkman, C. 1984. The genus Rubus (Rosaceae) in Malesia. 2. The subgenus Malachobatus. Blumea 29:319-386.

Kalkman, C. 1987. The genus Rubus (Rosaceae) in Malesia. 3. The subgenus Micranthobatus. Blumea 32:323-341.

Keep, E. 1958. Cytological notes, p. 75-78. In: Rpt. East Malling Res. Sta. 1957. East Malling, Maidstone, Kent, England.

Longley, A.E. 1924. Cytological studies in the genus Rubus. Amer. J. Bot. 11:249-282.

Longley, A.E. and G.M. Darrow. 1924. Cytological studies of diploid and polyploid forms of raspberries. J. Agr. Res. 27:737-748.

Macbride, J.F. 1938. Flora of Peru, p. 1096-1103. In: Field Museum of Natural History Botanical Series. vol. 13, part 2, no. 3. Publ. 428, Chicago.

Malik, C.P. 1965. Cytology of some Indian species of Rosaceae. Caryologia 18:139-149.

Naruhashi, N. and Y. Iwatsubo. 1993. Chromosome number of Japanese Rubus. Acta Hort. 352:429433.

Nybom, H. 1980. Chromosome numbers in Rubus species from Sri Lanka. Bot. Notiser 133:47-48.

Nybom, H. 1986. Chromosome numbers and reproduction in Rubus subgenus Malachobatus. Plant Syst. Evol. 152:211-218.

Rozanova, M.A. 1939. Role of autoploidy in the origin of the Siberian raspberry. C.R. (Doklady) Acad. Sci. URSS 24:58-60.

Snow, R. 1963. Alcoholic hydrochloric acid-carmine as a stain for chromosomes in squash preparations. Stain Technol. 38:9-13.

Stanley, T.D. and E.M. Ross. 1983. Flora of Southeastern Queensland. Queensland Dept. of Primary Industries Misc. Publ. 81020. Brisbane, Australia.

Taylor, R.L. and G.A. Mulligan. 1968. Flora of the Queen Charlotte Islands. Part 2. Cytological aspects of the vascular plants. Queen's Printer, Ottawa.

Thomas, P.T. 1940. The origin of new forms in Rubus. III. The chromosome constitution of $R$. loganobaccus Bailey, Its parents and derivatives. J. Genet. 40:141-156.

Thompson, M.M. 1995. Chromosome numbers of $R u$ bus cultivars at the National Clonal Germplasm Repository. HortScience 30:1453-1456.

Thompson, M.M. and C.M. Zhao. 1993. Chromosome numbers of Rubus species in southwest China. Acta Hort. 352:493-499.

Vaarama, A. 1954. Chromosome numbers of some species and hybrids of the genus Rubus. Arch. Soc. Zoology Bot. Fennicae 'Vanamo' 8:192-195.

Weber, H.E. 1972. Die Gattung Rubus L. im nordwestlichen Europa. Phanerogamarum Monographiae Tomus VII. J. Cramer, Lehre, Germany.

Weber, H.E. 1981. Revision der Corylifolii (Gattung Rubus, Rosaceae) in Skandinavien und im nördlichen Mitteleuropa. Paul Parey, Hamburg und Berlin.

Weber, H.E. 1986. Zur Nomenklatur und Verbreitung der von K.E.A. Weihe aufgestellten Taxa der Gattung Rubus L. (Rosaceae). Bot. Jahrbuch Syst. 106:289-335

Weber, H.E. 1991. Kommentierte Checkliste der Österreich nachgewiesenen Arten der Gattung $R u$ bus L. (Rosaceae). Phyton 31:67-79.

Williams, C.F., B.W. Smith, and G.M. Darrow. 1949. A pan-American blackberry hybrid. J. Hered. 40:261-265.

Yarnell, S.H. 1936. Chromosome behavior in blackberry-raspberry hybrids. J. Agr. Res. 52:385-396.

Yü, T.T. (ed.). 1985. Flora republicae popularis sinicae tomus 37. Science Press, Beijing.

Zandee, M. and C. Kalkman. 1981. The genus Rubus (Rosaceae) in Malesia. 1. Subgenera Chamaebatus and Idaeobatus. Blumea 27:75-113. 